A publication of the Muma College of Business | University of South Florida

\title{
INNOVATING ICT SKILLS FOR THE 4TH INDUSTRIAL REVOLUTION ${ }^{1}$
}

\author{
How can we, in collaborative partnership with different sectors, prepare South Africans to \\ beneficially participate in the digital economy and the 4th industrial revolution?
}

The new CEO of a year, Mymoena Ismail, pondered on how to re-invigorate the once dynamic and highly innovative government entity as part of three integrated government entities. The National Electronic Media Institute of South Africa (NEMISA) had existed for close to 20 years, having been created soon after the new democratic dispensation of South Africa. The key purpose of NEMISA, at that time, had been to fill a need in the broadcasting market of South Africa by up-skilling marginalised sectors of society, particularly African women, in broadcasting technology. A gap that traditional tertiary educational institutions were not filling had been identified. However, the landscape of broadcasting had transformed and was now heavily driven by ICT. For example, multimedia and graphic design were now primarily driven on ICT platforms and no-longer done on paper. The South African government was now categorizing previous broadcasting concepts such as multimedia, sound engineering, creative arts and graphic design under the ICT banner. Such changes in the broadcasting industry reflected a wider acceptance of what was now referred to as the digital or knowledge economy (Drucker 1978; Schwab 2017). In the digital age, access to knowledge using ICT was a critical tool and commodity in the derivation of economic benefit. The rise of intelligence in ICT systems, more popularly known as the $4^{\text {th }}$ industrial revolution or Industry 4.0, had already began to replace some lower-skilled jobs.

The questions at the top of her mind therefore revolved around how to transform the government agency into an agency that prepared South Africans with the new kinds of ICT skills that were needed in the medium to long term future. The existing ICT skills as offered at traditional educational institutions did not necessarily consider the context of South Africa nor were the skills tailored for the average employee. Would the transformation require the agency to become an educational institution, and / or a research and development agency that regularly identified change in the ICT sector and continually made recommendations on how to update the ICT skills courses? Such changes would require a different mandate from government.

\footnotetext{
${ }^{1}$ Copyright $($ 2 2018, Hossana Twinomurinzi and Mymoena Ismail. This case was prepared for the purpose of class discussion. Names and some information have been disguised. This case is published under a Creative Commons BY-NC license and originally appeared as a chapter in Transforming Society Using ICT: Contemporary Discussion Cases from Africa. Permission is granted to copy and distribute this case for non-commercial purposes, in both printed and electronic formats.
} 


\section{South Africa}

Located at the southernmost geographical point of Africa (Exhibit 1), by the end of 2016 South Africa had the second highest Gross Domestic Product (GDP) per capita in Africa after Nigeria (World Bank 2016). From a global perspective, South Africa was an upper-middle-income economy (Exhibit 2). Despite being the second largest economy in Africa, South Africa had the most advanced infrastructureinfrastructure that compared favourably with very high income countries. Historically, the economy had been heavily dependent upon the country's rich mineral resources. More recently, these had been affected by labour challenges such as strikes and a call for the mining sector to contribute more equitably to the South African economy (Adeleke 2017; Webster 2017).

Governance in South Africa was exercised through three non-hierarchical tiers: national, provincial and municipal. While each tier exercised a degree of autonomy, each was regarded as being interdependent and interrelated. The unique role of the national government affected the country; for example, the National Departments of Defence. The provincial tier operated within the national tier guidelines and had different administrative departments unique to the particular province. An example of a provincial department that was not reflected directly in the national department was the provincial department of Tourism, Economic Affairs, Environmental Affairs and Nature Conservation which were often bundled together (South Africa 1997). The municipal tier was supported and coordinated by the provincial tier. It was at the municipal level that all the policies and fundamental services were delivered. There were 278 municipalities in South Africa, comprising of eight metropolitans, 44 districts and 226 local municipalities.

The South African economy had over the previous 5 years (since 2012) been growing but at a slower rate than had been experienced over the previous decade (Trading Economics 2017). Among other reasons, the slowing growth rate had been attributed to two years of drought and a shrinking of the manufacturing sector. The biggest challenges that faced the country were widely acknowledged to be poverty, unemployment and inequity (South Africa 2013). These three challenges were largely viewed as an effect of the distinct role that apartheid had played in the recent history of South Africa. In the apartheid era, opportunities for social and economic growth, and human settlements had been segregated based on race. The current government efforts were therefore mainly directed towards dealing with the three challenges and ensuring that there was better access to development opportunities across all income and populations groups.

\section{The National Development Plan of South Africa}

South Africa had since 2010 had a National Development Plan (NDP) (South Africa 2013) that spelt out what development meant for South Africa. Although the NDP had been received with mixed feelings at the time of its release, it had eventually become accepted as making clear what development meant for South Africa.

The NDP sought to visualise where South Africa intended to be by 2030. It focused on what it regarded as the 15 critical issues that South Africa faced, and gave descriptive measures on how it hoped to get there. The underlying essence of these critical issues were nonetheless grounded in the understanding that poverty, unemployment and inequality were matters that were at the core of South Africa's challenges. The core of the NDP was therefore aimed at eliminating poverty, reducing inequality, creating an inclusive economy and building individual, community and societal capabilities.

The NDP, in the same character as the constitution, advocated for a collaborative approach to addressing the complexities that faced South Africa. It perceived that ICT had a role to play and provided latitude for 
how ICT would play that role in the collaborative approach. The strategies to achieve development were viewed as interlinked and would involve more than one effort from a single entity. The NDP had since become a widely accepted document from a development perspective, especially since human development remained a globally debated notion. Development meant different things to different individuals, communities, societies and even nations (Cypher \& Dietz 2009). It followed that the role that ICT played with respect to contributing to human development in South Africa would therefore have to be aligned with the NDP. The NDP recognised that its ambitious goals could not be achieved in isolation but rather demanded all societies of South Africa work collaboratively. It was envisaged that NEMISA could play a role in providing a collaborative platform that brought together the different sectors of society. Yet, working out the precise role ICT would play in achieving that collaboration required a great deal of effort.

\section{Collaboration in South Africa: the challenges and opportunities}

Collaboration had always been put forth as the ideal working approach in South Africa. There had been an intention since 2013 to integrate NEMISA and two other government institutes, the e-Skills Institute (e-SI) and the Institute for Satellite and Software Applications (ISSA), into one government entity called the iKamva National e-Skills Institute (iNESI). The e-Skills initiative had been a highly successful government flagship programme between 2010-2013 that had managed to bring together academics, industry, government, civil society and international donors and collaborate on e-skilling South Africa. The e-SI was however not a legal entity. ISSA was still based in Cape Town where it had been established with the primary purpose of offering postgraduate qualifications in satellite engineering and software development.

NEMISA needed to engage in two types of collaborative efforts: internal and external. Internally, NEMISA needed to merge with two other distinct government entities and become one government entity. Externally, NEMISA needed to collaborate with the non-governmental sector, particularly academia, business and civil society to achieve a socially appropriated usage of ICT in South Africa.

Internal collaboration between government entities was in practice often more difficult to implement. Government needed a great deal of national consultation before decisions could be implemented, a process that could easily take years. Government, which is so different from the private sector, had a responsibility towards all the citizens and not only those who were aligned to the political party in power. Hence, any decision or policy needed to pass through many legal and bureaucratic channels so as to adequately assess any impact on society as a whole.

An advantage that NEMISA had was that it operated as a semi-autonomous government agency and therefore enjoyed some degree of flexibility in decision making. The merger of three distinct government entities nevertheless presented both an opportunity and a complexity. The three options for the merger were either: (i) not to merge but have the e-Skills Institute persist as a separate legal entity from NEMISA (at a significant cost); (ii) have an integrated legal entity (which was not possible because the e-Skills institute was not a legal entity); or (iii) have a public entity with its own enabling legislation (which had better long-term benefits). The latter option, although the best (and possibly only viable) option was nonetheless going to take a substantial period of time.

Externally, NEMISA also needed to bring together multiple entities with very different agendas and priorities, including government, business, academia and civil society. Such a collaboration presented its own set of opportunities and challenges. Bureaucracy was a necessity in government in order to ensure 
that no citizen was disadvantaged. The same bureaucracy was also viewed as the biggest obstacle in business. Working in a competitive environment, businesses were focused on ensuring that their products and / or services were relevant to their specific audience, and as such were more willing to try new innovations. Business, in trying to remain as efficient and as profitable as possible, could do away with the ever increasing human resource base if cheaper means—such as those often offered by ICT_-were possible. Businesses always appeared to be in a hurry, and as such were impatient with the speed of government's processes. Academics, in contrast, strived to make sense of nature, society and the environment, looking at questions such as how society influenced technology, or how technology influenced society. It was also the dual mandate of academics to ensure that evidence-based knowledge was disseminated and produced within society. Therefore, the academic sector had to ensure the development of curricula that were stable. Finally, civil society focused on the injustices committed to minority groups and tended to apply a great deal of pressure to address the specific needs of these groups.

NEMISA had established contracts with a number of academic institutions intended to aid it in identifying the new e-skills that were required across South Africa. The plan was to have one academic institution in each province of South Africa serve as a collaborative centre (called a Colab). At that time there were seven Colabs representing seven of the nine provinces (see Table 1). Each Colab had a thematic area for which they were expected to coordinate environmental scans across South Africa but test new e-Skills courses within the Province. The purpose of the Colab was to act as an independent agent in bringing together industry, civil society and other sectors within the thematic area. Mpumalanga and Free State were the two remaining provinces without representation. There was, however, dialogue on which University in each province could play the Colab role.

\section{Table 1: NEMISA Colabs}

\begin{tabular}{|l|l|l|}
\hline Colab Name & Host University & Province \\
\hline e-Inclusion and Social Innovation CoLab & $\begin{array}{l}\text { University of the } \\
\text { Western Cape }\end{array}$ & Western Cape \\
\hline e-Enablement for Effective Service Delivery CoLab & $\begin{array}{l}\text { Durban University of } \\
\text { Technology }\end{array}$ & KwaZulu Natal \\
\hline ICT for Rural Development CoLab & $\begin{array}{l}\text { Walter Sisulu } \\
\text { University }\end{array}$ & Eastern Cape \\
\hline $\begin{array}{l}\text { Creative New Media Industries CoLab, based at the National } \\
\text { Electronic Media Institute of South Africa (there were talks in } \\
\text { advanced stages to have this Colab at the Tshwane University of } \\
\text { Science and Technology) }\end{array}$ & NEMISA (interimly) & Gauteng \\
\hline Connected Health CoLab & University of Limpopo & Limpopo \\
\hline $\begin{array}{l}\text { Knowledge-based Economy and e-Social Astuteness (e-Literacy) } \\
\text { CoLab }\end{array}$ & $\begin{array}{l}\text { Vaal University of } \\
\text { Technology }\end{array}$ & Northern Cape \\
\hline e-Agro-Tourism CoLab & North-West University & North West \\
\hline
\end{tabular}

The Colabs had created a number of e-Skills related courses and had registered a number of successes in delivering them within the provinces. The environmental scans, similar to baseline studies, were supposed to identify the areas of future interest in the thematic area that remained to be completed. Some of the Colabs were not particularly keen on doing the environmental scans as there was no pre-defined approach on how to accomplish that task in South Africa. There needed to be some innovative approaches to doing the environmental scans. 
NEMISA was involved in a number of international partnerships, which involved collaboration with the BRICS countries (Brazil, Russia, India, China and South Africa) whereby NEMISA played a leading role in representing South Africa. Other collaborative partnerships involved leading ICT corporates such as Intel, IBM and Microsoft. The partnerships evolved around sharing resources such as data and strategy.

The collaborative model meant that academia had to make some concessions and allow for some flexibility in their curricula. It also meant government needed to continuously monitor the environment in order to create policies that were easy to implement, yet remained flexible. New models were therefore required to leverage the new capabilities that ICT was increasingly making available. NEMISA had argued that the e-skilling agenda was the most appropriate model to ready South Africa for the changing environment characterised and driven by ICTs. The concept of e-skills related to adopting creative and innovative uses of ICT locally. The fundamental thesis was that for local ICT innovations to occur, there needed to be in place skills and competencies ranging from digital literacy to high-end specialist ICT skills such as those found in computer science \{Formatting Citation\}.

\section{The e-Skills agenda and the e-readiness of South Africa}

The e-skills agenda had formally began with the National e-Skills Plan of Action (NeSPA) report of 2010 (NeSPA, 2010). NeSPA had been the culmination of two years' consultation across business, government, education and civil society in South Africa, with participation by international donor agencies, international IT Corporates and research coordinators. The five areas that had been identified for focused effort identified in NeSPA were:

- $\quad$ The alignment of an e-skilling agenda within existing developmental policy - national and international, budgeted for and linked with human capacity development

- The cultivation of cross-collaborative research on e-skills across the main four sectors of government, business, education and civil society

- $\quad$ The creation of a cascading hub-and-spoke type of collaborative administrative structure, which placed Universities at the centre of bringing together the sectors

- $\quad$ Improving economic access to internet and telecommunications

- The formation of a high-level advisory council that would take care of the interests of the different sectors

In the context of South Africa, seven e-skills had been identified at the time:

- $\quad$ e-Literacy Skills: the basic use of ICT such as the internet and email

- $\quad$ e-Participation and e-Democracy Skills: focusing on enhancing participative citizengovernment engagement

- $\quad$ e-Government/Governance Skills: to increase a more efficient and productive use of ICT within government

- $\quad$ e-Business Skills: aimed at increasing organizational efficiency and productivity

- $\quad$ e-User Skills: focusing on enhancing efficiency of people for any task at hand

- $\quad$ e-Practitioner Skills: the more traditional domain of mainstream ICT professionals

- $\quad$ e-Community Skills: aimed at communities for building social cohesion within local contexts, for example, to deal with crime, health and education

The e-skills agenda regarded impact as being measured based outcomes that included: 
- $\quad$ Employment readiness: a higher ability to get employed

- $\quad$ Effective e-governance and service delivery: using ICT to improve government services

- $\quad$ Business development: leveraging ICT to enhance business productivity

- $\quad$ Socio-economic development: an increase in national productiveness

- $\quad$ Research and development: to guide policy and curriculum development

South Africa was currently in the $65^{\text {th }}$ position out of 139 countries (an improvement of 10 positions) with regards to its overall e-readiness — an international measure that identified the extent to which a country innovated ICT to suit its local context (Word Economic Forum 2016). E-readiness identified the ability of certain countries to quickly adapt their national policies around how to reap local benefit from the rising digital economy, an economy that is supported and driven by ICTs. The e-readiness (networked readiness) report was based on four primary categories: the environment, the technical/cost/skills, usage and impact. E-readiness was therefore an aggregated score and not based solely on a single dimension. There was an expectation that South Africa, with its advanced infrastructure, $44^{\text {th }}$ position out of 139 countries in terms of infrastructure, ought to be performing better in the e-readiness rankings. The lowest score was in the degree to which there was a social impact as a result of the usage of ICT, where South Africa was ranked $89^{\text {th }}$.

For NEMISA to offer the e-Skills courses targeting different levels of competencies, it would need to become accredited within one or all of the three National Qualification Frameworks of South Africa. While such accreditation was possible, it could take years to achieve. Furthermore, it was not NEMISA's core business to offer courses but rather to provide policy direction for the creation of such courses. A collaboration with the academic sector would therefore be ideal should NEMISA be able to provide the stimulus for curriculum changes.

From the academic perspective, NEMISA was engaging in the discourse on the role that ICT played in human development, more commonly referred to as ICT for development (ICT4D).

\section{Human development and ICT4D}

The underlying spirit of ICT4D was that ICT had a role to play in human, social and economic development. Avgerou (2009) had broadly summarised the discourses on ICT4D as falling at the intersection of two juxtaposed continuums with one representing how human and social development occurred and other dealing with how ICT was innovated to contribute to the process of development when used as a tool (Exhibit 3). The main distinctions of the discourses assigned four roles of ICT: 1) as a means to enable transformation within the local context; 2) as a "best-practice" tool that could "force" transformation; 3) as carrying an implicit ability to engender and or disrupt power relations in society; and 4) as a precipitating agent that produced outcomes that were not intentional, but were rather a result of unintended consequences of using ICT.

The perspective of NEMISA fell under the understanding that ICT could be used as a means of social and economic transformation. In particular, NEMISA argued that it was the social appropriation of ICT that could make a meaningful contribution to human and social economic development (NeSPA 2010). NEMISA conceded that while South Africa had risen in its e-readiness ratings, its sub-rating on ereadiness with regards the usage of ICT for social and economic gains was a major challenge.

\section{$4^{\text {th }}$ industrial revolution}

The term knowledge economy was often interchanged with terms such as "the information society", "the digital economy", "the new economy” and even the "weightless economy” (Quah, 2009). The digital 
economy was characterised by the convergence of media (text, video, telephony and images) and the rapid advancement in the power of technology and communications infrastructure to generate, transmit and distribute the information at faster speeds and lower cost. The role of ICT in the digital economy was not in generating economic value but rather in the structures that ICT created in the generation, processing, distribution, and the application of knowledge (Melody, 2009). There had similarly been the emergence of a $4^{\text {th }}$ industrial revolution. In the $4^{\text {th }}$ industrial revolution, rapid advances in ICT that were disrupting the fundamental nature of business, government and society were acknowledged (Schwab 2017). ICT systems could now be embedded in biological and physical systems and assist in making intelligent decisions, thus limiting the need for human intervention to very high or skilled levels. The same ICT systems were further interconnected with each other through internet platforms.

Mymoena knew that governments played an important role in shaping the digital economy and how society and government participated in the $4^{\text {th }}$ industrial revolution. The importance that government placed on ICT structures could make a difference. For example, South Africa had previously made an attempt at transforming some of its rural areas into smart cities by creating centres that were powered by top of the range ICT. Initially, the effort had been under the banner of multi-purpose community centres and more recently, under the brand name of Thusong Service Centres (TSCs). Thusong was a local Sesotho terms that meant a place of relief. The vision that drove the TSCs was to create a single point in every municipality in South Africa with critical government representation and access to the internet. Despite the investments and the provision of access, the failure of people to socially appropriate the opportunities brought about by the access to ICT rendered TSCs as wired cities and not smart cities (Legoabe 2004). She knew that there had to be another approach, other countries had managed to adapt their policies to take advantage of the digital economies.

\section{Countries at the forefront of leveraging the digital economy and $4^{\text {th }}$ industrial revolution}

Mymoena recognised that while some other countries had leveraged the digital economy, every society was unique. For example, Malaysia and India had moved the focus from foreign direct investments in ICT to investments in indigenous companies. Malaysia had intentionally forced multinational corporations to employ local resources in the ICT sector. The decision had resulted in a brain-circulation where specialist ICT skills eventually returned to Malaysia (Lazonick 2009). South Korea had invested in its human capital by upgrading the quality of higher education and the employment opportunities available to indigenous high-tech labour. South Korea had purposefully created industries that could lure back critical ICT skills. South Korea's decision to offshore some ICT skills had additionally been a factor that had caused a change in the economic paradigm from looking for low-wage labour to perform low-wage work to low-wage labour to perform high-skilled work (Lazonick 2009).

The e-Skills institute had previously visited a number of countries that had socially appropriated ICT within their local context. These countries included Cuba, India, China, Malaysia, Singapore, Mexico, Kenya, Rwanda, Ireland, UK, USA, Australia and New Zealand. The model for the establishment of iNeSI has therefore been progressively established over several years through assessing those country's approaches. The iNESI approach had been debated, discussed and evaluated in a range of significant international forums and had been endorsed as an innovative, practical and relevant approach that had wide application in South Africa and other developmental economies. 


\section{The Decision}

Upon considering the context and environment of South Africa, Mymoena knew she needed to make some choices on how to progress the NEMISA agenda. With respect to the nature of NEMISA as a unified entity, she needed to make decisions with legal implications on the new mandate of NEMISA in combination with ISSA and the e-Skills initiative. The legal ramifications ranged from becoming a legal entity to creating new legislation that supported the creation of a new mandate that drove the e-Skills agenda. The option of a legal entity would be a costly exercise, the option of becoming an integrated entity was not legally possible since the e-Skills initiative was not a legal option, and the third option involved making a case for new legislation that supported a new NEMISA mandate. The third option could easily take years as legislative changes required parliamentary approvals. This was despite an urgency to prepare South Africa for a changing environment.

On an ongoing basis, it was necessary to manage and continue steering the existing arrangement with the different Colabs at NEMISA. The Colabs needed to continue creating courses while at the same time showing evidence for the changes that needed to be made to ICT skills courses. These activities had to be accomplished within limited financial constraints. The independence of academic institutions, and the ethos of research, had been a key reason for the choice of academic institutions to host Colabs. However, academic institutions were not necessarily quick at making curriculum changes.

The curriculum changes that were required also had to be based on some form of evidence. The environmental scans were urgently required to support the basis of the e-Skills courses that were currently on offer, as well as to support changes that were being suggested. However, progress on the environmental scans was not moving as fast as required. Researchers were not particularly renowned for speed in responding to new requests, with very limited funding, either.

\section{References}

Adeleke, F., 2017. How South Africa's mining industry can change its ways - Wits University. University of the Witwatersrand. Available at: https://www.wits.ac.za/news/latest-news/in-their-ownwords/2017/2017-03/how-south-africas-mining-industry-can-change-its-ways.html [Accessed June 17, 2017].

Avgerou, C., 2009. Discourses on Innovation and Development in Information Systems in Developing Countries’ Research. In E. Byrne, B. Nicholson, \& F. Salem, eds. Proceedings of the 10th International Conference on Social Implications of Computers in Developing Countries. Dubai, United Arab Emirates: Dubai School of Government, International Federation for Information Processing, p. 510.

Cypher, J.M. and Dietz, J.L., 2009. Preface to the Third Edition. In J. M. Cypher \& J. L. Dietz, eds. The process of economic development. London: Routledge, pp. xviii-xix. Available at: http://www.loc.gov/catdir/enhancements/fy0908/2007051285-d.html

Drucker, P.F., 1978. The Age of discontinuity: Guidelines to our changing society, New York: Harper and Row.

Lazonick, W., 2006. Globalization of the ICT labor force. In: Mansell, R., Avgerou, C., Quah, D., Silverstone, R. (Eds.), The Oxford Handbook of Information and Communication Technologies. Oxford University Press .... Oxford University Press, Oxford, p. xxi, 620 p. 
Legoabe, N., 2004. MPCCs as vehicles for service delivery and development communication. Service Delivery Review.

Melody, W., 2006. Markets and Policies in New Knowledge Economy. In: Mansell, R., Avgerou, C., Quah, D., Silverstone, R. (Eds.), The Oxford Handbook of Information and Communication Technologies. Oxford University Press, Oxford, pp. 55-74.

NeSPA, 2010. National e-Skills Plan of Action: e-Skilling the Nation for Equitable Prosperity and Global Competitiveness Department of Communications, ed. Available at: www.doc.gov.za

Quah, D., 2009. Introduction: The Knowledge Economy and ICTs. In: Mansell, R., Avgerou, C., Quah, D., Silverstone, R. (Eds.), The Oxford Handbook of Information and Communication Technologies. Oxford University Press, Oxford, p. xxi, 620 p.

Schwab, K., 2017. The fourth industrial revolution, Available at:

https://books.google.com/books?hl=en\&lr=\&id=OetrDQAAQBAJ\&oi=fnd\&pg=PT8\&dq=4th+industrial +revolution\&ots=XijJlTdupN\&sig=f3q41xkfqDK6cM9uWe843iaj8hs [Accessed June 23, 2017].

South Africa, 2013. National Development Plan 2030. Our Future-make it work T. Presidency, ed.

South Africa, 1997. Provincial Review Report, Available at: http://www.gov.za/documents/provincialreview-report

Trading Economics, 2017. South Africa GDP Growth Rate. Available at: http://www.tradingeconomics.com/south-africa/gdp-growth [Accessed January 31, 2017].

Webster, E., 2017. Marikana and Beyond: New Dynamics in Strikes in South Africa. Global Labour Journal, 8(2), pp. 139-158. Available at: https://mulpress.mcmaster.ca/globallabour/article/view/3045 [Accessed June 17, 2017].

Word Economic Forum, 2016. The Global Information Technology Report 2016, Networked Readiness Index, Online. Available at: http://reports.weforum.org/global-information-technology-report2016/networked-readiness-index/

World Bank, 2016. GDP per capita (current US\$), Available at: http://data.worldbank.org/indicator/NY.GDP.PCAP.CD?end=2015\&locations=ZA-NGEG\&start=2009. 


\section{Biographies}

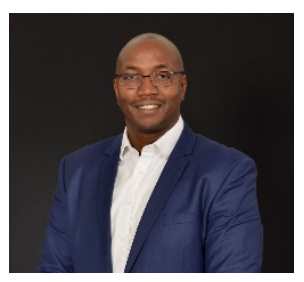

Hossana Twinomurinzi is a Professor in the School of Computing, University of South Africa. He has a BSc Hons (Mathematics) and a Masters and PhD in Information Technology. His principal research areas are in the role of ICT in development and egovernment. He is currently an Associate Editor of the African Journal of Information Systems and the Honorary Secretary of the South African Institute for Computer Scientists and Information Technologists (SAICSIT).

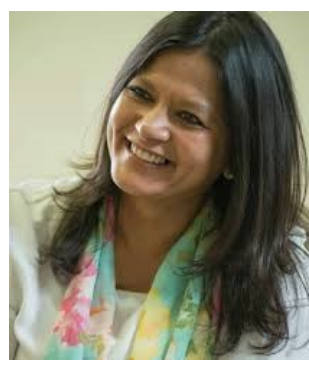

Mymoena Ismail is the Chief Executive Officer of NEMISA. NEMISA is responsible for the development of e-skills human capacity in our increasingly digital era. Mymoena has a long history with developing e-skills human capacity in South Africa. Her work has included being part of the team that designed and implemented a national model for the development of e-skills human capacity in this country, with the goal being to improve its World Economic Forum (WEF) rankings. 


\section{Exhibit 1: South Africa}

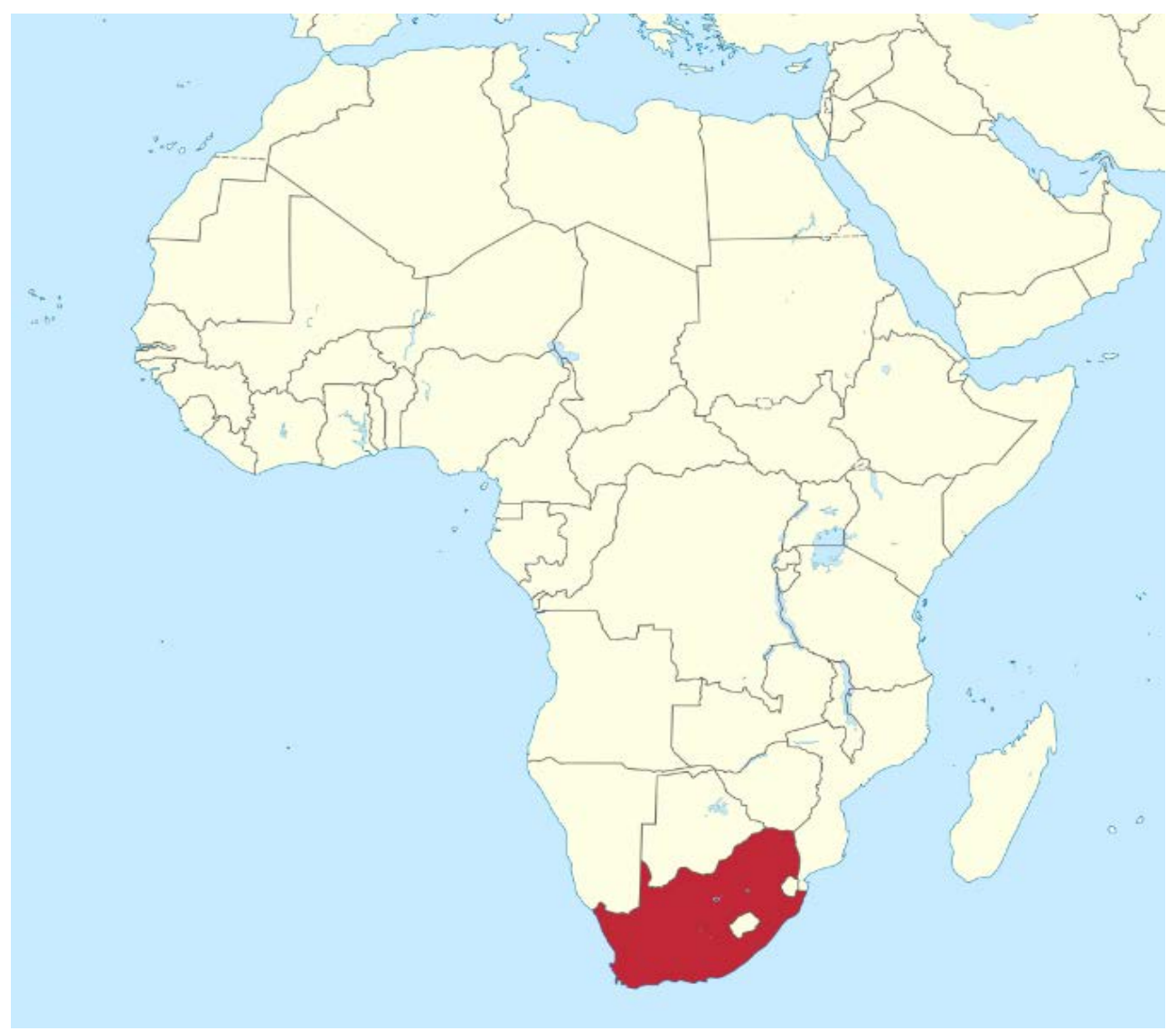




\section{Exhibit 2: South Africa GDP Growth Rate between January 2014-2017}

SOUTH AFRICA GDP GROWTH RATE

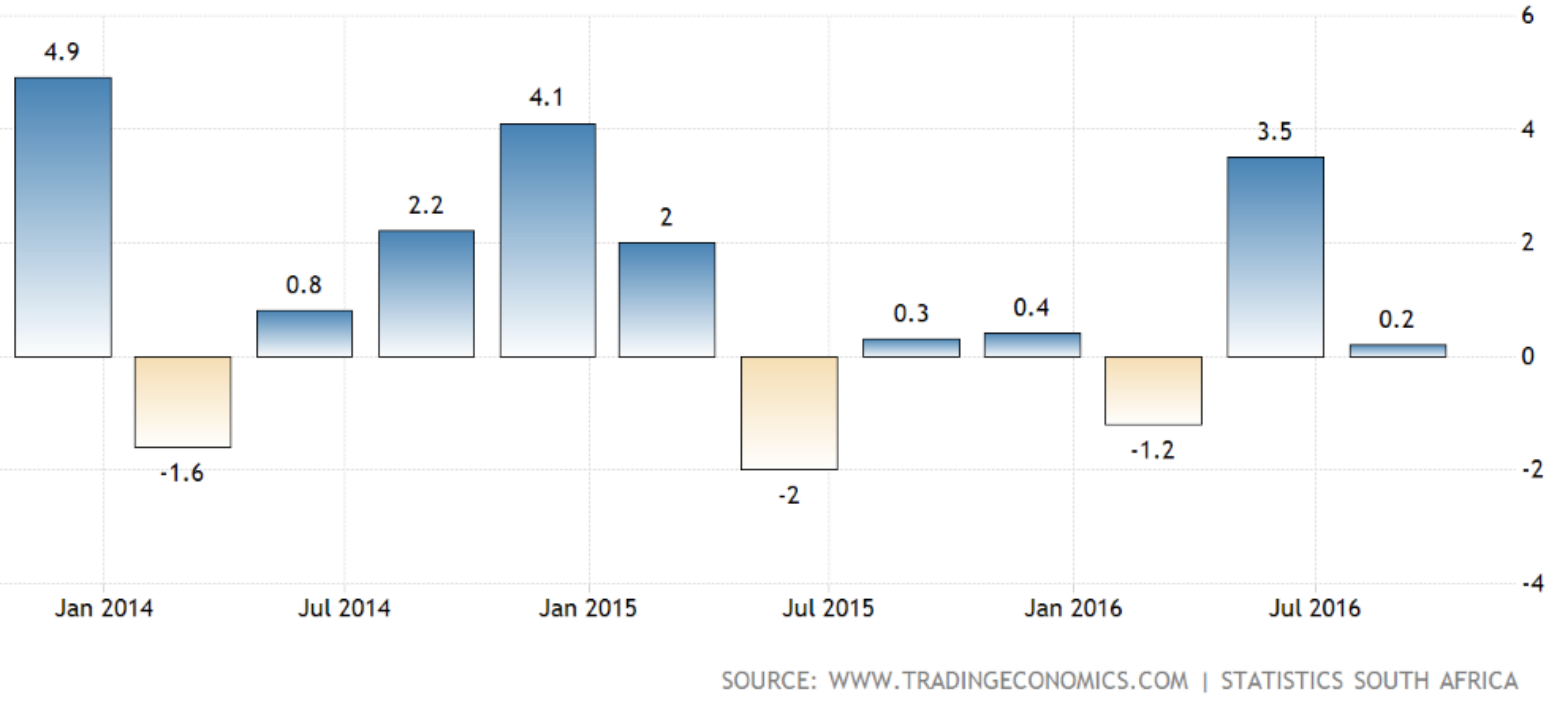




\section{Exhibit 3: Discourses on ICT4D}

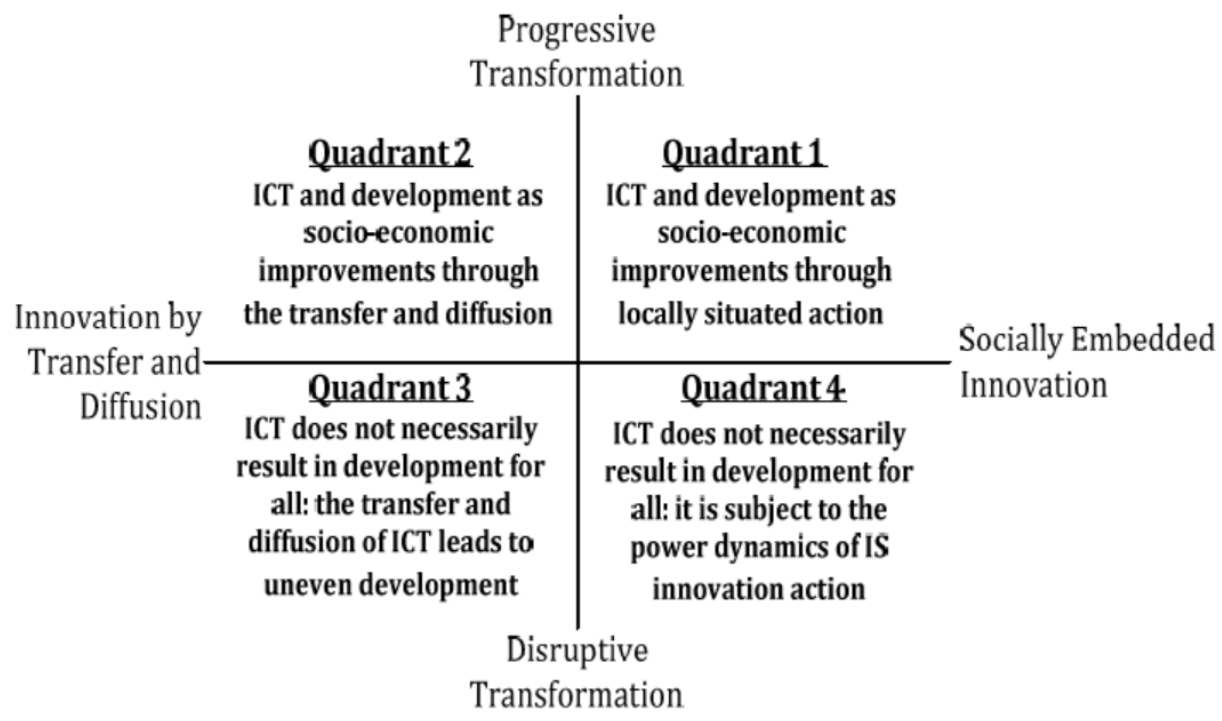

Source: Avgerou (2009) 